\title{
Effects of pretreatment with inhaled methoxamine on bronchial responses to histamine in asthmatic subjects
}

\author{
T.T.C. Phan-Puibaraud*, J. Regnard**, M. Monchi*, J. Dall'Ava-Santucci*, \\ A. Lockhart*, A.T. Dinh-Xuan*
}

Effects of pretreatment with inhaled methoxamine on bronchial responses to histamine in asthmatic subjects. T.T.C. Phan-Puibaraud, J. Regnard, M. Monchi, J. Dall'AvaSantucci, A. Lockhart, A.T. Dinh-Xuan. C ERS Journals Ltd 1995.

ABSTRACT: The underlying mechanisms of bronchial obstruction in asthma are complex. Both bronchospasm and bronchial oedema are thought to play pivotal roles in asthma, but their respective importance in a given asthmatic individual is unknown. To address this question, we assessed the effects of pretreatment with inhaled methoxamine, a potent $\alpha_{1}$-adrenoceptor agonist, on bronchial response to inhaled histamine in 10 asthmatic subjects.

The study was conducted according to a double-blind, cross-over, randomized and placebo-controlled design. In each subject, dose-response curves for the effects on forced expiratory volume in one second $\left(F E V_{1}\right)$ of serially doubling doses of inhaled histamine were obtained on three different days, 15 min after pretreatment with either methoxamine $(10 \mathrm{mg})$ or duplicated placebo. Histamine, first dose 100 $\mu \mathrm{g}(543 \mathrm{nmol})$, was delivered by a breath-activated dosimeter every $5 \mathrm{~min}$. FEV was measured in triplicate after each dose and the largest value was retained.

There was no difference in baseline and prechallenge $F E V_{1}$ after placebo and methoxamine. Mean coefficient of variation of decrease in $\mathrm{FEV}_{1}$ induced by histamine on the two placebo days was $6.7 \pm 2 \%$. On average, the bronchial responses to histamine were not modified by pretreatment with methoxamine as compared to placebo $(\triangle \mathrm{FEV}=0.83 \pm 0.14 l$ on methoxamine versus $0.85 \pm 0.11 l$ and $0.86 \pm 0.13 l$ on the two placebo days). However, using $95 \%$ confidence intervals of repeated measurements, analysis of individual results showed that the histamine-induced fall in $F_{E V}$ was significantly reduced by pretreatment with methoxamine in three subjects (Nos 3, 8 and 10); whereas, it was enhanced in three subjects (Nos 1, 4 and 9), and remained unchanged in the remaining four.

We conclude that the effects of methoxamine on the bronchial response to histamine are highly variable among asthmatic subjects. Methoxamine and histamine both cause contraction of bronchial smooth muscle, whereas methoxamine opposes the action of histamine in causing airways oedema. Therefore, we submit that histamine induced bronchial obstruction is reduced by methoxamine in asthmatic subjects in whom airflow obstruction is due mainly to bronchial oedema, whereas it is aggravated in patients with predominant bronchospasm.

Eur Respir J., 1995, 8, 40-46.

Airways narrowing in asthmatic subjects is not only caused by bronchospasm. There is now compelling evidence to suggest that mucosal and submucosal bronchial oedema is also instrumental in reducing airways patency $[1,2]$, thus causing airflow obstruction. Conditions which increase bronchial blood flow and microvascular leakage are likely to favour bronchial oedema [3, 4]; whereas, it is thereotically possible to lessen the degree of bronchial obstruction by reducing bronchial blood flow and microvascular permeability [5].

Methoxamine is an $\alpha_{1}$-adrenergic agonist [6] that can, through stimulation of postjunctional $\alpha_{1}$-adrenoceptors, contract bronchial smooth muscle $[7,8]$, reduce bronchial blood flow $[9,10]$, and inhibit microvascular leakage [11-13]. We have previously demonstrated that
* Service de Physiologie, Explorations Fonctionnelles, C.H.U. Cochin Port-Royal, Université René Descartes, Paris, France. **Laboratoire de Physiologie, Faculté de Médecine, Besançon, France.

Correspondence: A.T. Dinh-Xuan

Service de Physiologie

Explorations Fonctionnelles Hôpital Cochin

27, rue du fg Saint-Jacques

75679 Paris cedex 14

France

Keywords: Alpha ${ }_{1}$-adrenoceptor agonists asthma

bronchial oedema

bronchospasm

nonspecific bronchial hyperreactivity to histamine

Received: May 91994

Accepted after revision November 61994 pretreatment with inhaled methoxamine is effective against methacholine-induced bronchial obstruction in patients with left ventricular failure [14], and in the prevention of exercise-induced asthma of some teenagers suffering from mild asthma [15]. Recent data also suggest that methoxamine reduces the level of maximal airway narrowing induced by methacholine in young adults with asthma [16]. Over all, these results are best explained by the actions of methoxamine on the airways vascular bed rather than on bronchial smooth muscle.

Histamine is a potent agonist that causes bronchoconstriction [17], increase in bronchial blood flow [18, 19], and microvascular leakage of airways [11]. All these effects are known to contribute to airflow obstruction. However, we have previously suggested that the 
respective importance of these factors may vary greatly among asthmatic subjects [15]; and this variability remains to be assessed.

By studying the effect of pretreatment of inhaled methoxamine on the bronchial response to histamine, our aim was to assess the respective contribution of bronchial oedema and bronchospasm in narrowing the airways of asthmatic subjects. We hypothesized that if bronchial oedema was predominant, methoxamine, by reducing bronchial blood flow and microvascular leakage induced by histamine, should have beneficial effects in these subjects. Conversely, if bronchospasm was the main factor, methoxamine, by its agonist action on bronchial smooth muscle, would then potentiate histamine-induced bronchial obstruction.

\section{Methods}

\section{Subjects}

We studied 10 nonsmoking subjects ( 3 females and 7 males) aged 20-25 yrs (mean 23 yrs). All subjects had mild asthma, as evidenced by at least one asthma crisis in the previous 6 months, a personal history of atopy, and known bronchial hyperresponsiveness to inhaled histamine [20, 21]. All subjects had normal resting lung function, with mean forced expiratory volume in one second $\left(\mathrm{FEV}_{1}\right) 3.78 \pm 0.24 l(92 \pm 5 \%$ pred), range 2.77 $-5.37 l(72-115 \%$ pred $)$ that did not significantly vary during the study. None of the subjects was receiving anti-asthma medication on a regular basis, although some of them made occasional use of inhaled $\beta_{2}$-adrenergic agonists and/or cromoglycate. All therapy was suspended at least $72 \mathrm{~h}$ before each study, according to usual recommendations [22]. None of the subjects had suffered from an acute respiratory tract infection during the 6 weeks preceding the tests. The study was approved by the Ethics Committee of our Medical School, and informed consent was obtained from each subject who volunteered for the study.

\section{Outline of the study}

Each subject was studied on three different days at least $72 \mathrm{~h}$ apart, with an interval between the first and the last study day of less than 2 weeks. On each study day and at the same time of day, a dose-response curve for the effects on $\mathrm{FEV}_{1}$ of serially doubling doses of inhaled histamine was obtained after pretreatment with either placebo or methoxamine. The study day on placebo was duplicated, in order to assess reproducibility of bronchial responses to histamine. The study was double-blind and the three study days were randomly allocated. All subjects were asked to abstain from drinking tea or coffee between the preceding evening and the end of each trial day.

Each trial day started with the measurement of baseline $\mathrm{FEV}_{1}$, before and after inhalation of two doses of nebulized saline $(0.15 \mathrm{M} \mathrm{NaCl})$. Variation of less than $5 \%$ between pre- and postsaline values was required to allow the subject to enter the trial. Immediately afterwards, the subject inhaled methoxamine or placebo. After an interval of 15 min, $\mathrm{FEV}_{1}$ was measured again as a post-treatment value and histamine challenge was then started. At either the highest dose of histamine, or the dose for which there was a fall of $\mathrm{FEV}_{1} \geq 20 \%$ from baseline, the challenge was stopped and the subject inhaled two puffs $(2 \times 100 \mu \mathrm{g})$ of salbutamol. $\mathrm{FEV}_{1}$ was determined again $10 \mathrm{~min}$ later to assess reversibility of histamine-induced bronchial obstruction.

\section{Technical details}

Spirometric measurements. To avoid any operator bias in the measurement of $\mathrm{FEV}_{1}$, we used an automated electronic spirometer (Autospiro AS 500, Minato, Medical Science Co., Osaka, Japan), which was calibrated with a $3 l$ syringe at least once a week, and in previous studies produced $\mathrm{FEV}_{1}$ values comparable to those obtained with a water-sealed spirometer [20, 21]. At all timepoints, $\mathrm{FEV}_{1}$ was measured in triplicate, and the largest value was retained.

Inhalation procedures. Methoxamine and histamine were administered with a breath-activated dosimeter (Rosenthal-French, model D-2A, Laboratory for Applied Immunology, Baltimore, MD, USA) and a nebulizer (No. 646, DeVilbiss Co., Somerset, Pa, USA). The aerosol was produced by an oxygen flow at a pressure of 1.38 $\mathrm{kPa}$, and was inhaled during tidal breathing with the patient's nose occluded. Each activation of the dosimeter delivered a preset quantity of nebulized solution (output $120 \mu \mathrm{l} \cdot \mathrm{min}^{-1}$ ) in order to deliver the required amount of either methoxamine or histamine. Volume history was standardized by having each participant inhale from functional residual capacity to total lung capacity. Methoxamine hydrochloride (MW $247.5 \mathrm{~g}$ ) was diluted in $0.15 \mathrm{M} \mathrm{NaCl}$ at a concentration (W/V) of $40 \mathrm{~g} \cdot l^{-1}$. Osmolarity of the solution was $300 \mathrm{mosm} \cdot l^{-1}$, and $\mathrm{pH}$ 7. The dose of methoxamine delivered to each subject was $10 \mathrm{mg}$. The histamine challenge tests were performed according to standard recommendations [23]. Histamine dichloride (MW $184 \mathrm{~g}$ ) was diluted in 0.15 $\mathrm{M} \mathrm{NaCl}$ at a concentration of $10 \mathrm{~g} \cdot \mathrm{l}^{-1}$. The first dose of histamine delivered was $100 \mu \mathrm{g}(543 \mathrm{nmol})$. Thereafter, one to four serially doubling doses (2-16 times the initial dose) were administered at intervals of $5 \mathrm{~min}$, until a fall in $\mathrm{FEV}_{1} \geq 20 \%$ from prechallenge $\mathrm{FEV}_{1}$ was reached. A cumulative dose of 3,100 $\mu \mathrm{g}(8,688 \mathrm{nmol})$ of histamine was chosen as the end-point, even if a fall in $\mathrm{FEV}_{1} \geq 20 \%$ could not be achieved on some occasions, as we have previously noticed that higher doses of histamine might cause unpleasant side-effects such as intense headache and facial flush in some subjects. Provocative dose of histamine $\left(\mathrm{PD}_{10}\right)$ was calculated for each patient on each study day from the percentage change from prechallenge $\mathrm{FEV}_{1}$ versus $\log _{10}$ cumulative dose of histamine by linear interpolation. 
Table 1. - Individual maximal fall in $\mathrm{FEV}_{1}$ and $\mathrm{PD}_{10}$ measured on the three study days

\begin{tabular}{|c|c|c|c|c|c|c|c|c|}
\hline \multirow{2}{*}{$\begin{array}{l}\text { Subject } \\
\text { No. }\end{array}$} & \multicolumn{3}{|c|}{$\Delta \mathrm{FEV}_{1}^{*} l$} & \multirow[t]{2}{*}{$95 \% \quad \mathrm{CI}^{\#}$} & \multicolumn{3}{|c|}{$\mathrm{PD}_{10} \quad \mu \mathrm{g}$} & \multirow[t]{2}{*}{$95 \% \mathrm{CI}^{\#}$} \\
\hline & P1 & $\mathrm{P} 2$ & $\mathrm{Mx}$ & & $\mathrm{P} 1$ & $\mathrm{P} 2$ & $\mathrm{Mx}$ & \\
\hline 1 & 0.63 & 0.37 & 1.47 & $(0.25-0.75)$ & 173 & 294 & 60 & $(115-352)$ \\
\hline 2 & 0.57 & 0.33 & 0.68 & $(0.21-0.69)$ & 48 & 79 & 37 & $(33-94)$ \\
\hline 3 & 0.83 & 0.89 & 0.48 & $(0.80-0.92)$ & 47 & 25 & 62 & $(14-58)$ \\
\hline 4 & 0.60 & 0.75 & 0.98 & $(0.53-0.82)$ & 200 & 205 & 123 & (198-207) \\
\hline 5 & 1.00 & 1.62 & 1.20 & $(0.70-1.92)$ & 36 & 22 & 35 & $(15-43)$ \\
\hline 6 & 1.08 & 0.85 & 1.12 & $(0.74-1.19)$ & 233 & 137 & 178 & $(91-279)$ \\
\hline 7 & 0.40 & 0.65 & 0.50 & $(0.28-0.77)$ & 2860 & 2213 & 2151 & $(1902-3171)$ \\
\hline 8 & 0.97 & 0.77 & 0.22 & $(0.67-1.07)$ & 1051 & 2255 & $>3100$ & $(473-2833)$ \\
\hline 9 & 0.77 & 0.85 & 1.27 & $(0.73-0.89)$ & 38 & 39 & 34 & $(38-39)$ \\
\hline 10 & 1.67 & 1.53 & 0.42 & $(1.46-1.74)$ & 169 & 214 & 2191 & $(147-236)$ \\
\hline
\end{tabular}

*: $\triangle \mathrm{FEV}_{1}$ is the difference between baseline $\mathrm{FEV}_{1}$ and $\mathrm{FEV}_{1}$ obtained at the highest common dose of histamine on the three study days. \#: for values on the two days on placebo treatment. $\mathrm{FEV}_{1}$ : forced expiratory volume in one second; $95 \% \mathrm{CI}$ : 95\% confidence interval; $\mathrm{P} 1$ and $\mathrm{P} 2$ : placebo days 1 and 2; $\mathrm{Mx}$ : methoxamine; $\mathrm{PD}_{10}$ : provocative dose of histamine calculated from the percentage change from prechallenge $\mathrm{FEV}_{1}$ versus $\log _{10}$ cumulative dose of histamine by linear interpolation.

\section{Statistical analysis}

Homogeneity of baseline $\mathrm{FEV}_{1}$ on the three study days, and before and after inhalation of $0.15 \mathrm{M} \mathrm{NaCl}$, was tested by a two-way analysis of variance (ANOVA) [24]. Post-treatment values of $\mathrm{FEV}_{1}$ obtained $15 \mathrm{~min}$ after methoxamine or placebo were compared to baseline values by a two-way ANOVA. The nonparametric Friedman test [24] was used to compare $\mathrm{PD}_{10}$ and the maximal fall in $\mathrm{FEV}_{1}\left(\Delta \mathrm{FEV}_{1}\right)$, expressed as the difference between baseline $\mathrm{FEV}_{1}$ and the lowest $\mathrm{FEV}_{1}$ obtained at the highest common dose of histamine for each patient on the three study days. Ninety five percent confidence interval $(95 \% \mathrm{CI})$ of repeated measurements of $\mathrm{PD}_{10}$ and $\triangle F E V_{1}$ on the two placebo days were determined for each individual (table 1). Pretreatment with methoxamine was deemed to have an effect when both $\triangle \mathrm{FEV}_{1}$ and $\mathrm{PD}_{10}$ measured on the methoxamine study day exceeded the $95 \%$ CI limits on placebo periods. From this, three subgroups of subjects were individualized, according to whether methoxamine caused a greater, a smaller, or no change in bronchial responsiveness to histamine as compared with the duplicated placebo periods. Analysis of variance was again applied to assess statistical significance between methoxamine and placebo within each of the three subgroups. Correlation was sought using simple linear regression between the degree of bronchial reversibility, as measured by the increase in $\mathrm{FEV}_{1}$ after salbutamol over baseline $\mathrm{FEV}_{1}$, (bronchodilatory index), and the effect of methoxamine on bronchial responsiveness to histamine, as measured by the difference between the mean of the lowest $\mathrm{FEV}_{1}$ obtained on the two placebo days (P1 and $\left.\mathrm{P} 2\right)$ and the lowest $\mathrm{FEV}_{1}$ obtained on methoxamine $(\mathrm{Mx})$ (methoxamine index), according to the following formula:

$$
[(\mathrm{P} 1+\mathrm{P} 2) / 2]-\mathrm{Mx}
$$

Thus, a positive value for this difference reflects a larger fall in $\mathrm{FEV}_{1}$ on methoxamine as compared to placebo, i.e. an increased bronchial responsiveness, whereas a negative value reflects a decreased responsiveness to histamine.

All results are expressed as mean \pm sEM. Values of $\mathrm{p}<0.05$ were considered statistically significant.

\section{Results}

\section{Group-average results}

There was no difference in baseline FEV $\mathrm{F}_{1}$ on methoxamine $(3.75 \pm 0.25 l)$ and the two placebo days $(3.75 \pm 0.23$

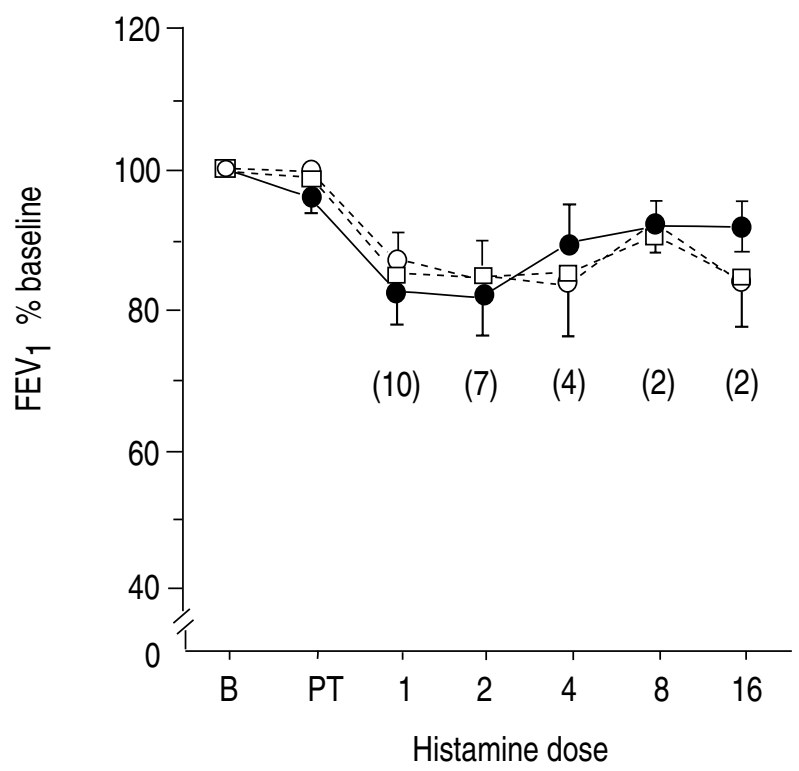

Fig. 1. - Average dose-response curves for the effects on $\mathrm{FEV}_{1}(\%$ baseline) of successive doubling doses of histamine $(1=100 \mu \mathrm{g} ; 16=$ $1,600 \mu \mathrm{g})$ after pretreatment with methoxamine (-) or placebo 1 and $2(-\mathrm{O}$ and $-\square$, respectively). B and PT: FEV 1 measured at baseline and 15 min after pretreatment with methoxamine or placebo. Numbers in brackets indicate the number of subjects actually tested with a given cumulative dose of inhaled histamine. Note that the vertical axis is cut off from zero. $\mathrm{FEV}_{1}$ : forced expiratory volume in one second. 
and $3.76 \pm 0.26 l$, respectively). On average, there was no modification in resting prechallenge $\mathrm{FEV}_{1}$ measured 15 min after inhalation of either methoxamine $(3.61 \pm 0.26 l)$ or $0.15 \mathrm{M} \mathrm{NaCl}$ on placebo days $(3.74 \pm 0.25$ and $3.75 \pm$ $0.25 \mathrm{l}$, respectively). Comparison of group-average dose-response curves to histamine obtained on methoxamine or placebo showed no significant difference between the three curves (fig. 1). Similarly, maximal fall in $\mathrm{FEV}_{1}$ $\left(\triangle \mathrm{FEV}_{1}\right)$ at the highest common dose of histamine obtained on the methoxamine day $(0.83 \pm 0.14 l)$ did not significantly differ from those obtained on the two placebo days $(0.85 \pm 0.11$ and $0.86 \pm 0.13 l$, respectively).

\section{Individual results}

Individual results showed a highly variable pattern of response among subjects when looking at the dose-response curve obtained on methoxamine as compared to the two dose-response curves obtained on placebo (fig. 2). The latters were, however, superimposable (coefficient of variation ranging $2.4-7.8 \%$ ) in all but one subject (No. 5), in whom the coefficient of variation between the two placebo days was $23.6 \%$.
Analysis of individual $\triangle \mathrm{FEV}_{1}$ and $\mathrm{PD}_{10}$ (table 1) showed that three subjects (Nos. 1, 4 and 9) had increased responsiveness to histamine (higher $\triangle \mathrm{FEV}_{1}$ and lower $\mathrm{PD}_{10}$ ) after pretreatment with methoxamine as compared with the two placebo periods $(\mathrm{p}<0.05)$ (table 1 and fig. $3 \mathrm{~b}$ ). Decreased responsiveness (lower $\triangle \mathrm{FEV}_{1}$ and higher $\mathrm{PD}_{10}$ ) was found in three subjects (Nos. 3, 8 and 10) (table 1 and fig. 3c). In the four remaining subjects (Nos. 2, 5, 6 and 7), methoxamine was deemed having no effect on bronchial response to histamine as $\triangle \mathrm{FEV}_{1}$ and $\mathrm{PD}_{10}$ obtained on the methoxamine day were within the $95 \% \mathrm{CI}$ of the two placebo days (table 1 and fig. 3a).

\section{Bronchial reversibility}

Significant correlation was found between the degree of bronchial reversibility (bronchodilatory index) and the effect of methoxamine on bronchial responsiveness to histamine (methoxamine index) $(\mathrm{r}=0.69 ; \mathrm{p}<0.05)$, (fig. 4). Patients in whom responsiveness to histamine was increased by methoxamine also had the largest bronchodilatory response to salbutamol.

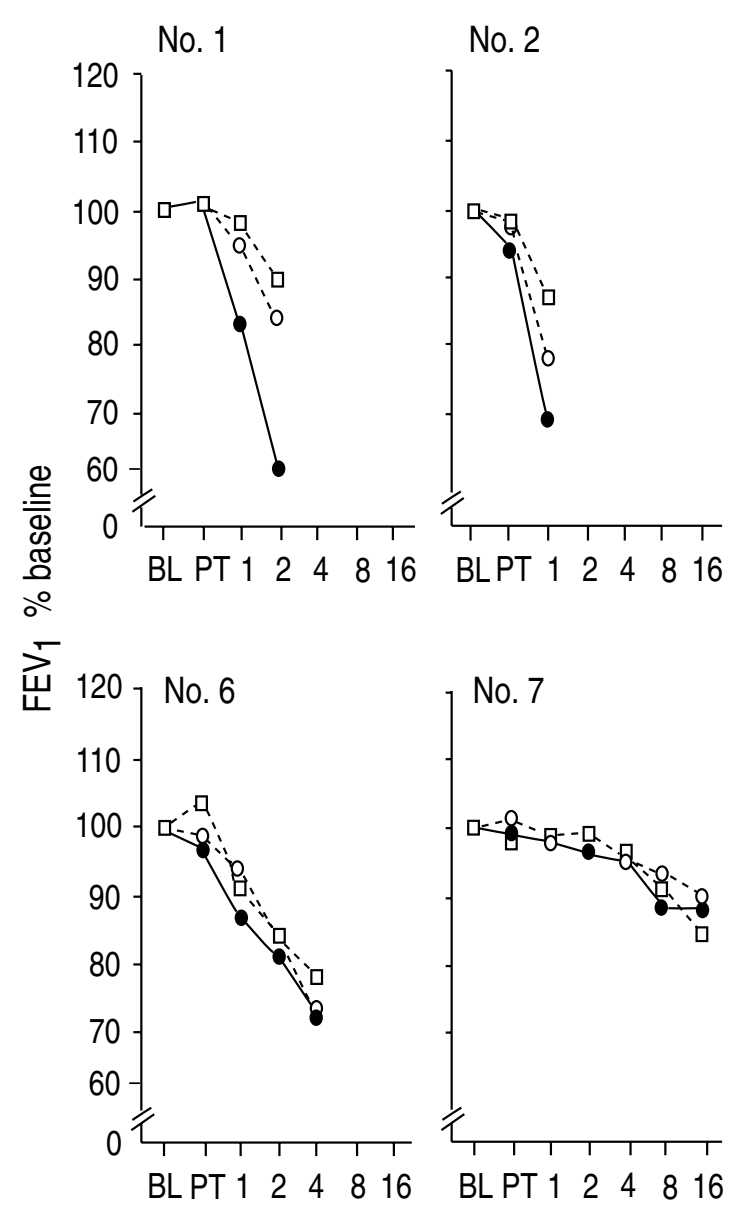

No. 3

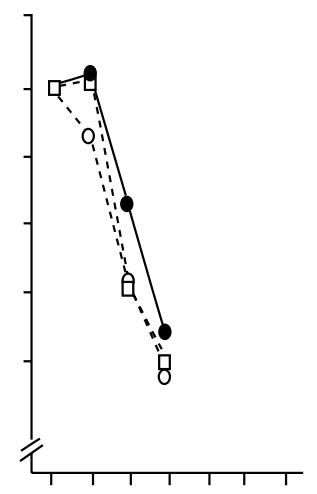

BLPT $1224 \quad 816$
No. 4
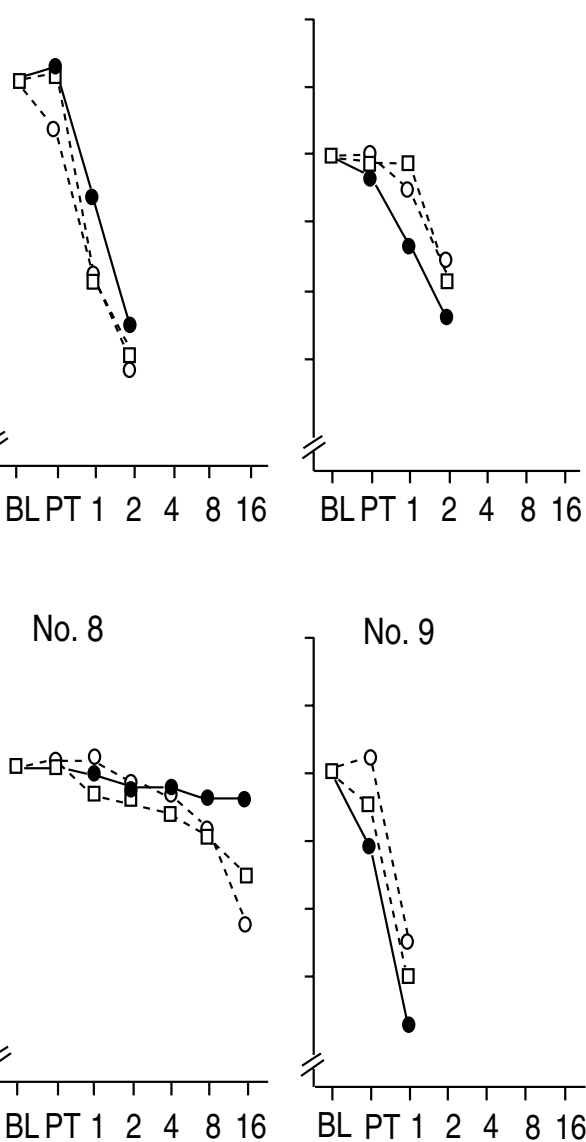

No. 9

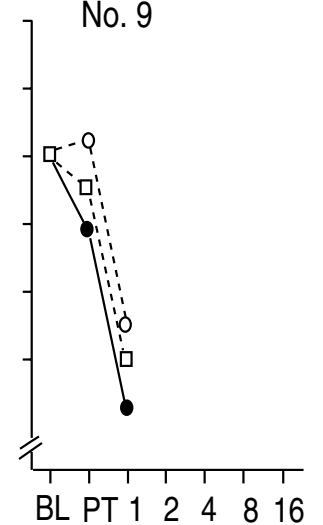

No. 5

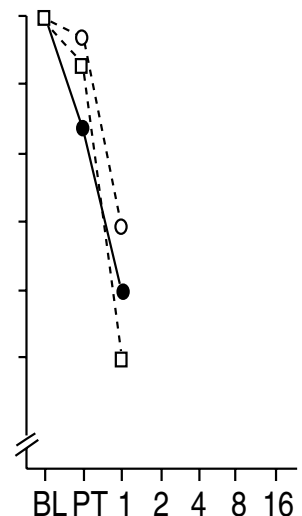

\section{Histamine}

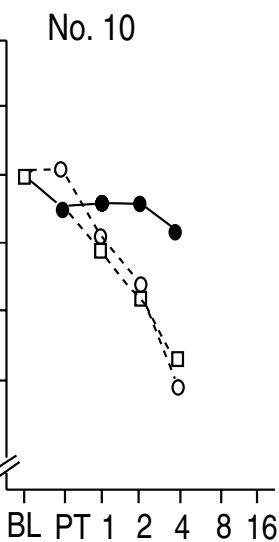

Fig. 2. - Individual dose-response curves, after pretreatment with methoxamine ( - - ) or placebo $(\bigcirc, \square)$. See legend to figure 1 for full explanation. 

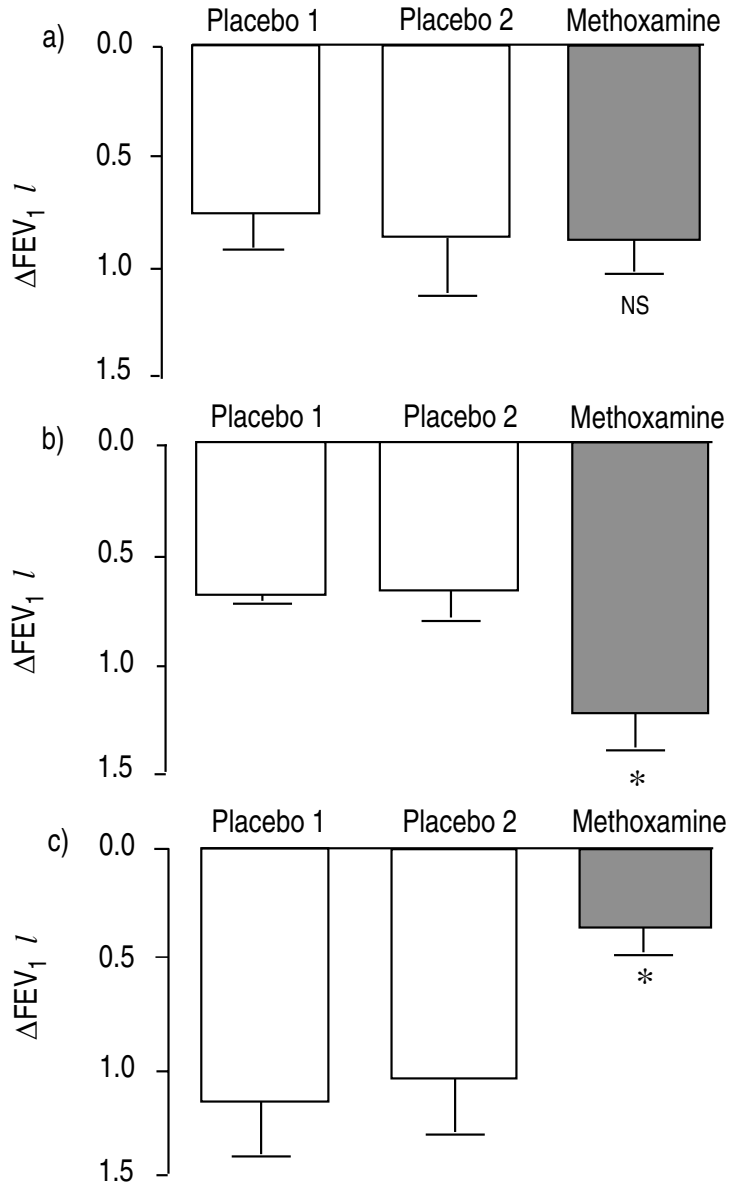

Fig. 3. - Group means maximal fall in $\operatorname{FEV}_{1}\left(\Delta \mathrm{FEV}_{1}\right)$ in subjects in whom pretreatment with methoxamine (closed column) either had no effect (Nos 2, 5, 6 and 7) (a), increased (Nos 1, 4 and 9) (b) or decreased (Nos 3, 8 and 10) (c) on the bronchial responses to histamine as compared with the two placebo periods (open columns). $\mathrm{FEV}_{1}$ : forced expiratory volume in one second; NS: not significant; *: $\mathrm{p}<0.05$ as compared with placebo treatment periods.

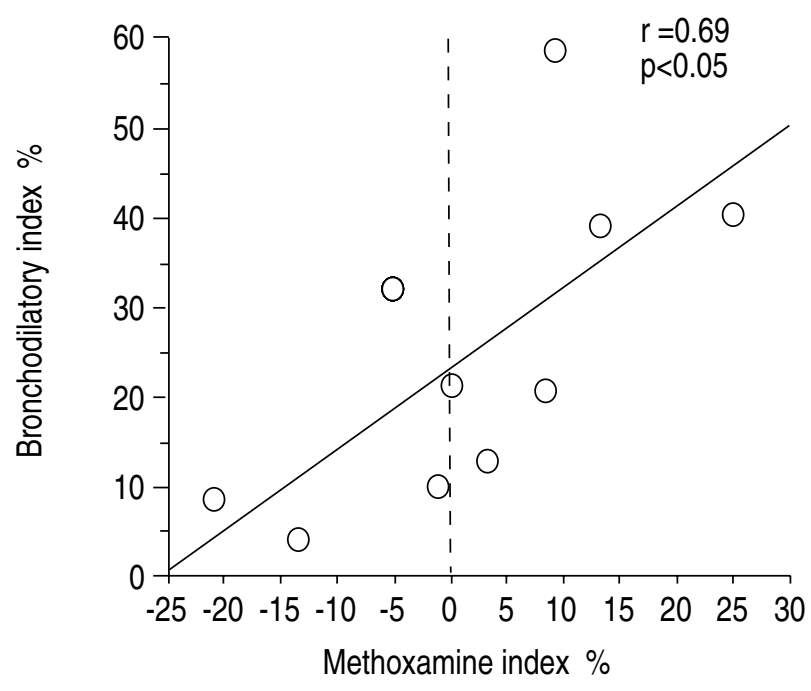

Fig. 4. - Correlation between bronchial reversibility after salbutamol (bronchodilatory index) and the effect of methoxamine on bronchial responses to histamine (methoxamine index). Positive values on the abscissa indicate enhanced bronchial responsiveness to histamine induced by methoxamine as compared to placebo, whereas negative values indicate reduced bronchial responsiveness.

\section{Discussion}

The main finding of this study is that pretreatment with inhaled methoxamine did not, on average, alter the bronchial response to histamine in subjects suffering from mild asthma. There were, however, marked differences between subjects. Indeed, histamine-induced bronchial obstruction was reduced by pretreatment with methoxamine in three subjects, aggravated in three, and remained apparently unaffected in the remaining four subjects.

Design of the study, i.e. inhalation of $10 \mathrm{mg}$ of methoxamine $15 \mathrm{~min}$ prior to the histamine challenge, has been chosen in accordance with results of our previous studies $[14,15]$. Indeed, inhalation of methoxamine, used at the same dose and the same interval, was effective in preventing methacholine-induced bronchial obstruction in patients with left ventricular failure [14], exerciseinduced asthma in teenagers [15], and maximal airway narrowing to methacholine in atopic asthmatic adults [16]. A second placebo day was studied to test the intraindividual reproducibility of dose-response curves to histamine. The consistent superimposable slope of the two dose-response curves on placebo allows us to rule out any possible bias due to random daily variation of nonspecific bronchial hyperreactivity in all but one subject (No. 5). It seems, therefore, that any change in the slope or the end-point of the curves observed after methoxamine is more likely to be the result of pharmacological effects of the latter rather than intraindividual variation of bronchial responsiveness to histamine.

Methoxamine is one of the selective agonists for $\alpha_{1}$,adrenoceptors [6] that may have various effects on human airways. Those agonists contract isolated bronchial smooth muscle [7, 8], enhance in vitro secretion of airways submucosal glands [25], and facilitate histamine release from sensitized human lung tissue [26]. These effects probably account for the development of bronchial obstruction ascribed to stimulation of $\alpha_{1}$-adrenoceptors in some asthmatic subjects [7, 27-29]. They are also consistent with reported beneficial effects of various $\alpha_{1}$-adrenoceptor antagonists in asthma [30-32]. However, neither the consistency of $\alpha_{1}$-adrenoceptor agonists in causing bronchial obstruction nor the specificity of $\alpha_{1}$-adrenoceptor antagonists to prevent it are unanimously recognized $[33,34]$, and there is debate as to the relevance of using $\alpha_{1}$-adrenoceptors blocking drugs in asthma [34].

Controversies about the bronchoconstrictor effects of $\alpha_{1}$-adrenoceptor agonists probably relate to the fact that their potential effects on the bronchial circulation and microvascular permeability have been somewhat over-

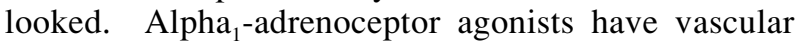
effects that can reduce bronchial blood flow $[9,10]$, and inhibit microvascular leakage of airways $[11,12]$. It is, therefore, reasonable to predict beneficial effects of $\alpha_{1}$-adrenoceptor agonists in conditions where bronchial oedema is likely to occur. Indeed, we have shown that pretreatment with inhaled methoxamine could either reduce or suppress bronchial obstruction induced by methacholine in patients with left heart failure [14], and 
partially prevent exercise-induced asthma in teenagers [15]. Recent data from a study by CHEUNG et al. [16] are also consistent with a beneficial effect of methoxamine in reducing methacholine-induced maximal airway narrowing in asthma. In all these conditions, either direct or circumstantial evidence of presence of oedema in the airways has been provided [35-37]. However, an acute asthma crisis occurred with inhalation of methoxamine in one subject from our second study [15], highlighting differences among individuals in response to bronchial $\alpha_{1}$-adrenoceptor stimulation.

Histamine has several pharmacological effects that may contribute to narrow the airways of asthmatic subjects. It contracts isolated bronchial smooth muscle [17], increases bronchial blood flow in a variety of experimental conditions [18, 19], enhances mucus secretion from cultured cells [38], and favours microvascular leakage to large molecules in the airways [11].

Comparison of their pharmacological properties indicates that histamine and methoxamine are similar with regard to their effects on bronchial smooth muscle and glands. However, they strongly differ and even have opposite effects upon the bronchial vasculature. Indeed, as a potent vasoconstrictor, not only could methoxamine reduce the increased bronchial blood flow, but it might also prevent the occurrence of microvascular leakage caused by histamine and, as a result, lessen the degree of airways oedema. This is probably the explanation for the beneficial effects of methoxamine in subjects Nos. 3,8 and 10 . By contrast, the aggravation of histamineinduced bronchial obstruction caused by pretreatment with methoxamine in subjects Nos. 1, 4 and 9 is probably a reflection of predominant bronchospasm, as both agonists are acting in concert causing contraction of bronchial smooth muscle. Alternatively, by reducing mucosal blood flow, methoxamine may impede the clearance of histamine from the airways. As a result, this might increase local concentrations of histamine and, therefore, potentiate its effects upon various target cells in the airways.

Subjects in whom salbutamol had a greater bronchodilatory effect were also those who had enhanced bronchial responsiveness to histamine after methoxamine. This suggests that bronchospasm might be the predominant factor in causing airway narrowing in these subjects. Conversely, the smaller bronchial reversibility with salbutamol was observed in subjects who had reduced bronchial responsiveness to histamine after methoxamine. In these, vascular congestion, rather than constriction of bronchial smooth muscle, is probably the main factor contributing to narrowing the airway. The apparent lack of effect of methoxamine in the five remaining subjects could be the result of absence, or scarcity, of pulmonary $\alpha_{1}$-adrenoceptors. Alternatively, this could be explained by an even degree of bronchospasm and bronchial oedema, which might, in turn, balance the putative beneficial and deleterious effects of methoxamine on airways patency in these subjects.

In conclusion, we were able to demonstrate marked interindividual differences in the effects of methoxamine in this small group of asthmatic subjects. Although they need confirmation, our results also suggest that histamine has a greater action on bronchial smooth muscle, relative to mucosa, compared with methacholine and exercise, as the protective effect of methoxamine is more consistent with the latter [14-16] than with histamine. Whilst reconciling previous controversial results obtained with $\alpha_{1}$-adrenoceptor agonists, our study also demonstrated the uneven importance of various factors causing bronchial obstruction among asthmatic subjects. Refining the syndrome may, therefore, prove necessary in order to more specifically target drugs to be effectively used in asthma.

\section{References}

1. Wanner A. Circulation of the airway mucosa. J Appl Physiol 1989; 67: 917-925.

2. Bucca C, Rolla G. Mucosal oedema and airway hyperreactivity. Eur Respir J 1989; 2 (Suppl. 6): 520s-522s.

3. Chung KF, Rogers DF, Barnes PJ, Evans TW. The role of increased microvascular permeability and plasma exudation in asthma. Eur Respir J 1990; 3: 329337.

4. Regnard J, Dinh-Xuan AT, Matran R. Mécanismes de l'hyperréactivité bronchique: l'œdème bronchique, les facteurs mécaniques et vasculaires. Rev Mal Respir 1994; 11: 161-170.

5. Dinh-Xuan AT. Bronchial blood flow and microvascular permeability in the pathophysiology of asthma. Med Hypotheses 1990; 32: 207-209.

6. Starke K. Alpha $a_{1}$-adrenoceptor subclassification. Rev Physiol Biochem Pharmacol 1981; 88: 199-236.

7. Simonsson BG, Svedmyr N, Skoogh BE, Anderson R, Bergh NP. In vivo and in vitro studies on alphareceptors in human airways: potentiation with bacterial endotoxin. Scand J Respir Dis 1972; 53: 227-236.

8. Kneussl MP, Richardson JB. Alpha-adrenergic receptors in human and canine tracheal and bronchial smooth muscle. J Appl Physiol: Respirat Environ Exercise Physiol 1978; 45: 307-311.

9. Lung MA, Wang JCC, Cheng KK. Bronchial circulation: an autoperfusion method for assessing its vasomotor activity and the study of $\alpha$ - and $\beta$-adrenoceptors in the bronchial artery. Life Sci 1976; 19: 577-580.

10. Laitinen LA, Robinson NP, Laitinen A, Widdicombe JG. Relationship between tracheal mucosal thickness and vascular resistance in dogs. J Appl Physiol 1986; 61: 2186-2193.

11. Person CGA, Svensjö E. Airway hyperreactivity and microvascular permeability to large molecules. Eur J Respir Dis 1983; 64 (Suppl 131): 183-214.

12. Boschetto P, Roberts NM, Rogers DF, Barnes PJ. Effect of anti-asthma drugs on microvascular leakage in guinea-pig airways. Am Rev Respir Dis 1989; 139: 416-421.

13. Larrazet F, Chauveau M, Weber S, Lockhart A, Frossard $\mathrm{N}$. Inhibition of substance P-induced microvascular leakage by inhaled methoxamine in rat airways. $\mathrm{Br} \mathrm{J}$ Pharmacol 1994; 113: 649-655.

14. Cabanes LR, Weber SN, Matran R, et al. Bronchial hyperresponsiveness to methacholine in patients with impaired left ventricular function. N Engl J Med 1989; 320: $1317-1322$.

15. Dinh-Xuan AT, Chaussain M, Regnard J, Lockhart A. 
Pretreatment with an inhaled $\alpha_{1}$-adrenergic agonist, methoxamine, reduces exercise-induced asthma. Eur Respir J 1989; 2: 409-414.

16. Cheung D, Nagtegaal, Sont JK, Dijkman JH, Sterk PJ. The effect of an inhaled $\alpha_{1}$-adrenoceptor agonist methoxamine on maximal airway narrowing to methacholine in atopic asthmatic subjects in vivo (Abstract). Am J Respir Crit Care Med 1994; 149: A1052.

17. Armour CL, Lazar NM, Schellenberg RR, et al. A comparison of in vivo and in vitro human airway reactivity to histamine. Am Rev Respir Dis 1984; 129: 907-910.

18. Long WM, Sprung CL, El Fawal H, et al. Effects of histamine on bronchial artery blood flow and bronchomotor tone. J Appl Physiol 1985; 59: 254-261.

19. Charan NB, Turk GM, Ripley R. Measurement of bronchial arterial blood flow and bronchovascular resistance in sheep. J Appl Physiol 1985; 59: 305-308.

20. Dinh-Xuan AT, Regnard J, Matran R, Mantrand P, Advenier C, Lockhart A. Effects of clonidine on bronchial responses to histamine in normal and asthmatic subjects. Eur Respir J 1988; 1: 345-350.

21. Dinh-Xuan AT, Matran R, Regnard J, Vitou P, Advenier C, Lockhart A. Comparative effects of rilmenidine and clonidine on bronchial responses to histamine in asthmatic subjects. Br J Clin Pharmacol 1988; 26: 703-708.

22. American Thoracic Society. Guidelines for bronchial inhalation challenges with pharmacologic and antigenic agents. ATS News 1980; 11.

23. Eiser NM, Kerrebijn KF, Quanjer PH. Guidelines for standardization of bronchial challenges with (nonspecific) bronchoconstricting agents. Bull Eur Physiopathol Respir 1983; 19: 495-514.

24. Armitage P, Berry G. Statistical methods in medical research. 2nd edn. Oxford: Blackwell, 1987.

25. Phipps RJ, Nadel JA, Davis B. Effect of alpha-adrenergic stimulation on mucus secretion and on ion transport in cat trachea in vitro. Am Rev Respir Dis 1980; 121: 359-365.

26. Kaliner M, Orange RP, Austen KF. Immunological release of histamine and slow reacting substance of anaphylaxis from human lung. IV. Enhancement by cholinergic and alpha-adrenergic stimulation. J Exp Med 1972; 136: 556-567.

27. Patel KR, Kerr JW. The airways response to phenylephrine after blockade of alpha- and beta-receptors in extrinsic bronchial asthma. Clin Allergy 1973; 3: 439-448.

28. Snashall PD, Boother FA, Sterling GM. The effect of $\alpha$-adrenoreceptor stimulation on the airways of normal and asthmatic man. Clin Sci 1978; 54: 283-289.

29. Black JL, Salome CM, Yan K, Shaw J. Comparison between airway response to an $\alpha$-adrenoceptor agonist and histamine in asthmatic and nonasthmatic subjects. Br J Clin Pharmacol 1982; 14: 464-466.

30. Kerr JW, Govindaraj M, Patel KR. Effect of alphareceptor blocking drugs and disodium cromoglycate on histamine hypersensitivity in bronchial asthma. $\mathrm{Br} \mathrm{Med}$ $J$ 1970; 2: 139-141.

31. Walden SM, Bleecker ER, Chahal KS, Britt EJ, Mason P, Permutt S. Effect of alpha-adrenergic blockade on exercise-induced asthma and conditioned cold air. Am Rev Respir Dis 1984; 130: 357-362.

32. Barnes PJ, Wilson NM, Vickers H. Prazosin, an alpha ${ }_{1}-$ adrenoceptor antagonist, partially inhibits exercise-induced asthma. J Allergy Clin Immunol 1981; 68: 411-415.

33. Thomson NC, Daniel EE, Hargreave FE. Role of smooth

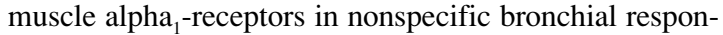
siveness in asthma. Am Rev Respir Dis 1982; 126: 521-525.

34. Barnes PJ. State of art: neural control of human airways in health and disease. Am Rev Respir Dis 1986; 134: 1289-1314.

35. Renault P, Paley PY, Lenègre J, Caruso G. Les altérations bronchiques des cardiaques. J Fr Med Chir Thorac 1943; 3: 141-159.

36. Gilbert IA, Fouke JM, McFadden ER Jr. Heat and water flux in the intrathoracic airways and exercise-induced asthma. J Appl Physiol 1987; 63: 1681-1691.

37. James AL, Paré PD, Hogg JC. The mechanics of airway narrowing in asthma. Am Rev Respir Dis 1989; 139: 242-246.

38. Shelhamer JH, Marom Z, Kaliner M. Immunologic and neuropharmacologic stimulation of mucous glycoprotein release from human airways in vitro. J Clin Invest 1980; 66: $1400-1408$. 